\title{
Traumatic Isolated Levator Palpebrae Superioris Muscle Laceration: A Case Report
}

\author{
Travmatik Izole Levator Palpebra Süperior Kas Kesisi: Bir Olgu Sunumu
}

\author{
Can Pamukcu', Sabit Kimyon², Alper Mete², Gülcihan Açıș3 , Halil Hüseyin Çağatay ${ }^{4}$ \\ ${ }^{1}$ Ophthalmology Clinic, Private Hatem Hospital, Gaziantep, Turkey; ${ }^{2}$ Ophthalmology Clinic, Şehitkamil State Hospital, Gaziantep, Turkey; \\ ${ }^{3}$ West Eye Hospital, Erbil, Iraq; ${ }^{4}$ Department of Ophthalmology, Kafkas University Medical Faculty, Kars, Turkey
}

\begin{abstract}
A 34 year-old man was brought to emergency room after a car accident. Left upper eyelid laceration was sutured during transport, because the frontal sinus was open. In this paper, we report a case of a man with craniofascial trauma diagnosed through a simple usual examination in the emergency room and received the proper interventions.
\end{abstract}

Key words: blepharoptosis; levator-oculomotor synkinesis; orbital fractures; wounds and injuries

\section{ÖZET}

Araba kazası sonrası 34 yașında bir erkek hasta acil servise getirildi. Tașınma sırasında, üst göz kapağı, frontal sinüs açık olduğu için dikilmiști. Bu yazıda, acil serviste basit genel muayene ile tanı ve uygun tedavi alan kraniyofasyal yaralanmalı bir erkek hastayı sunuyoruz.

Anahtar kelimeler: blefaropitoz; okülomotor-levator sinkinezi; orbita kırıklarl; yaralar ve hasarlar

\section{Introduction}

Craniofascial traumas can lead to eyelid edema, compression or damage of occulomotor nerve and ptosis. Clinical course and prognosis may depend on the quality of the management efforts. In this paper, we report a case of a man with craniofascial trauma diagnosed through a simple usual examination in the emergency room (ER) and received the proper interventions.

\section{Case Report}

A 34 year-old man was brought to ER after a car accident. Left upper eyelid laceration was sutured during transport, because the frontal sinus was open.

Uzm. Dr. Sabit Kimyon, Şehitkamil Devlet Hastanesi Gaziantep, Türkiye Tel.05055814450Email.pamukcu.can@gmail.com

Geliş Tarihi: 26.01.2014 • Kabul Tarihi: 12.10.2014
The patient is evaluated in ER. He was able to count fingers from a distance of six meters. Bio-microscopic evaluation was unremarkable except mildly dilated pupil on the left side. Levator muscle function was evaluated by making the patient to look up and down.

Levator muscle function and upper skin crease were absent on the left side (Figure 1). The sutures on the left upper eyelid were opened. At the level of the superior fornix, levator palpebra superior muscle was detached and the laceration was at the base of the brow (Figure 2). Although the anterior wall of the frontal sinus was fractured, the aeration of the sinus was good and there was no bone fragments inside it. In addition, an irregular laceration of the upper canalicular system with tissue loss was observed.

Initially, levator muscle was sutured from both edges. Then the conjunctiva and skin were sutured with 8.0 polyglactine and 6.0 polyglactine surgical sutures, respectively. Lower canalicular system was patent. The upper canalicular system was not operated due to the tissue loss and irregular laceration. The patient also had corneal hypoestesis.

During the six months of postoperative visits the patient had ptosis of the left eyelid (Figure 3). Levator functional test result was $4 \mathrm{~mm}$ at last visit, thus a secondary $10 \mathrm{~mm}$ levator resection surgery was performed.

At the final stage, cosmetic satisfaction was acceptable (Figure 4) and the patient did not request for a frontalis suspension surgery. In addition, he had no complaint about epiphora and the lower canalicular system was still intact. 

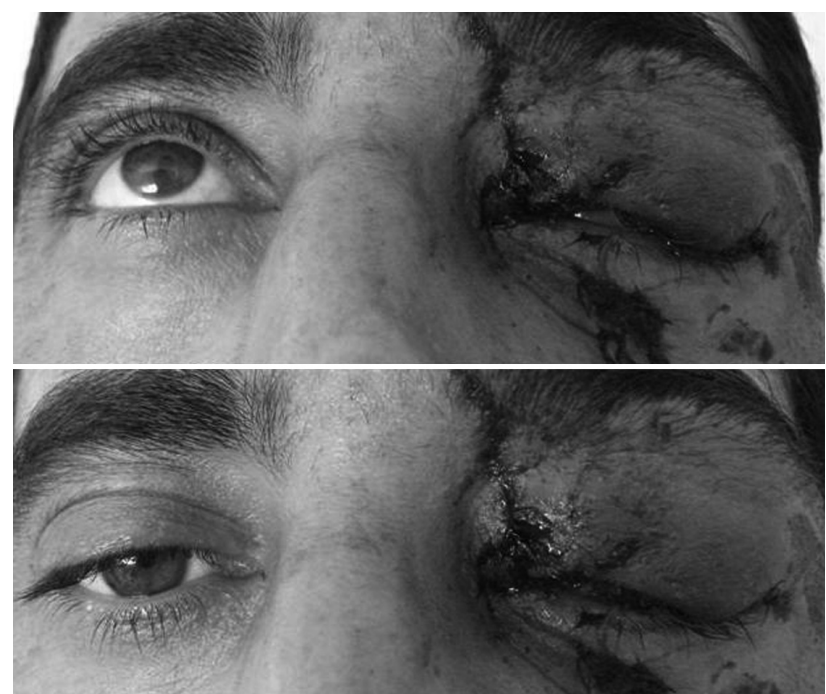

Figure 1. Appearance of the patient in emergency room. Upper left eyelid was not moving upword.

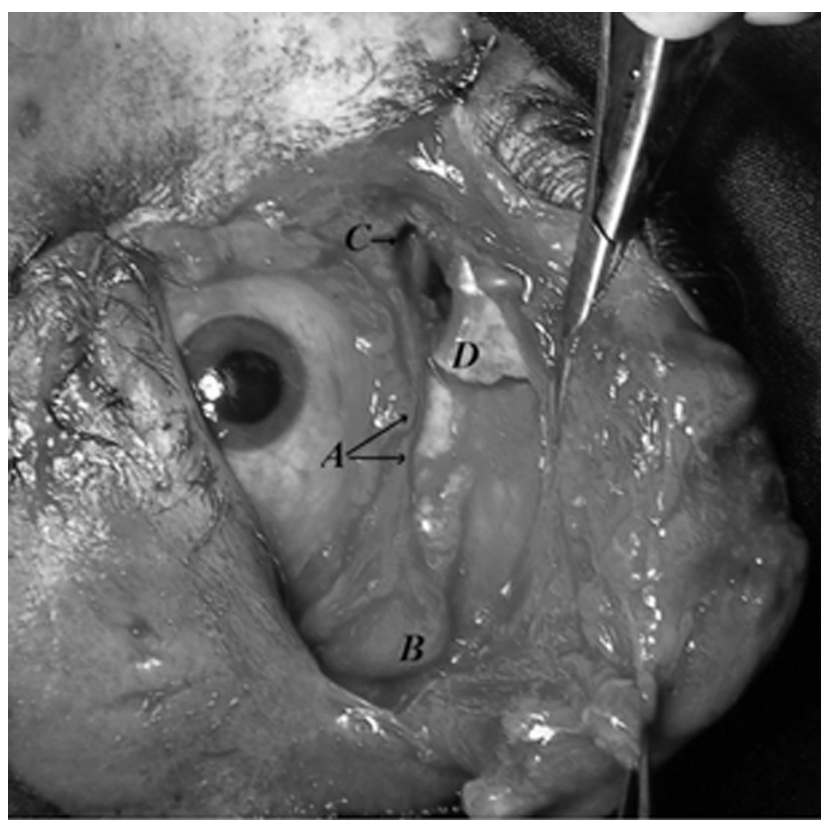

Figure 2. The appearance of the injury following the removal of previously placed sutures: A) Superior fornix conjunctiva and levator palpebrae superioris muscle complex; B) Lacrimal gland; C) Opening of the frontal sinus to the fracture line; D) Superior orbital rim and fragmented fracture of the anterior wall of the frontal sinus.

\section{Discussion}

Traumatic ptosis is common after deep eyelid lacerations and avulsions. In these cases exploration and tissue identification is necessary in order to reunite the damaged structures, appropriately.

In $16 \%$ of the eyelid traumas, lacrimal system is also involved ${ }^{1}$. Thus, lacerations adjacent to medial canthus need nasolacrimal irrigation in order to see if there is
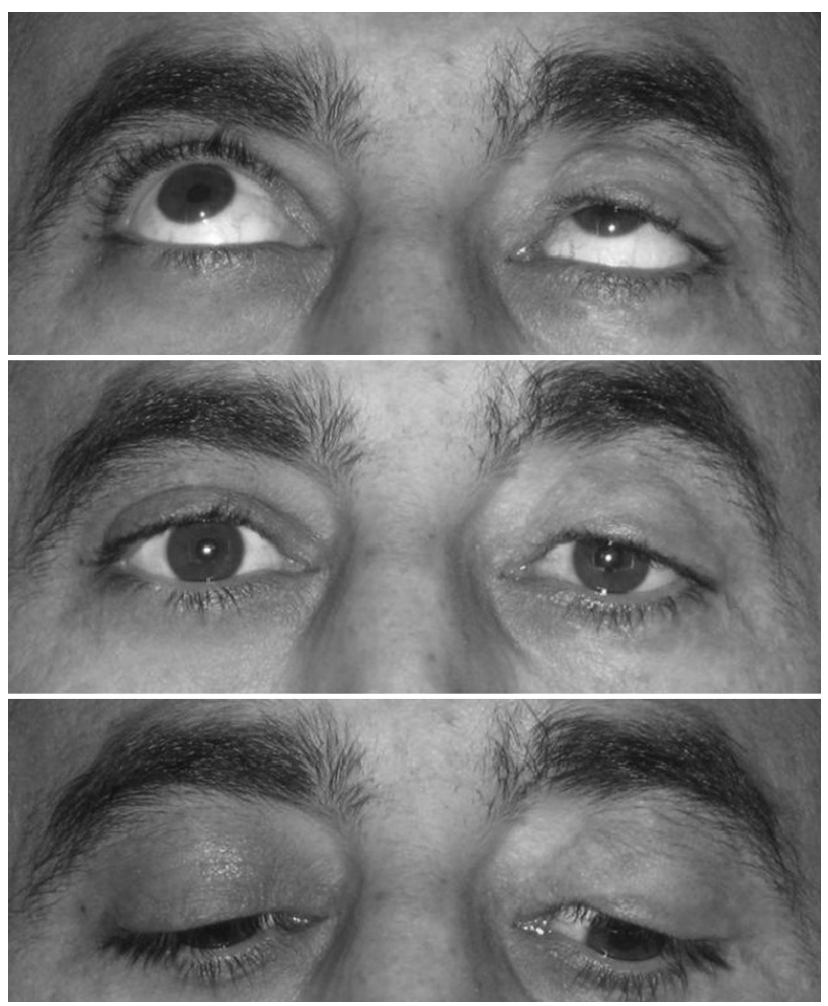

Figure 3. The appearance of the eyelid after six months during upward and downward gaze.

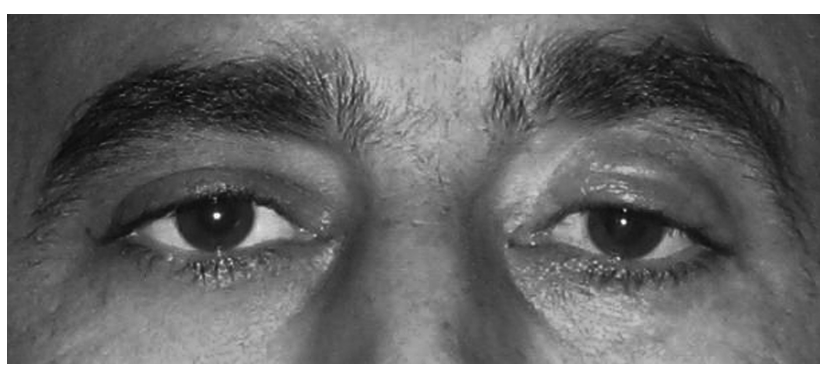

Figure 4. Appearance of the patient after left levator muscle resection surgery.

any lacrimal system damage. Our case had an irregular upper canalicular laceration with tissue loss, thus we only repaired the upper eyelid without including the upper canalicular system.

In eyelid trauma cases, even if there is periocular edema, levator muscle will form a skin crease (Figure 5). Because our patient didn't have a skin crease, we had the suspicion of a levator muscle laceration and confirmed it after the removal of the previously placed sutures. Although the suspicion of occulomotor nerve paralysis occurred at that stage, we reunited the edges of the levator muscle to form the anatomic unity, because the ptosis following trauma and ischemia can improve spontaneously in four to six months 2 . Therefore, we needed to wait six months 

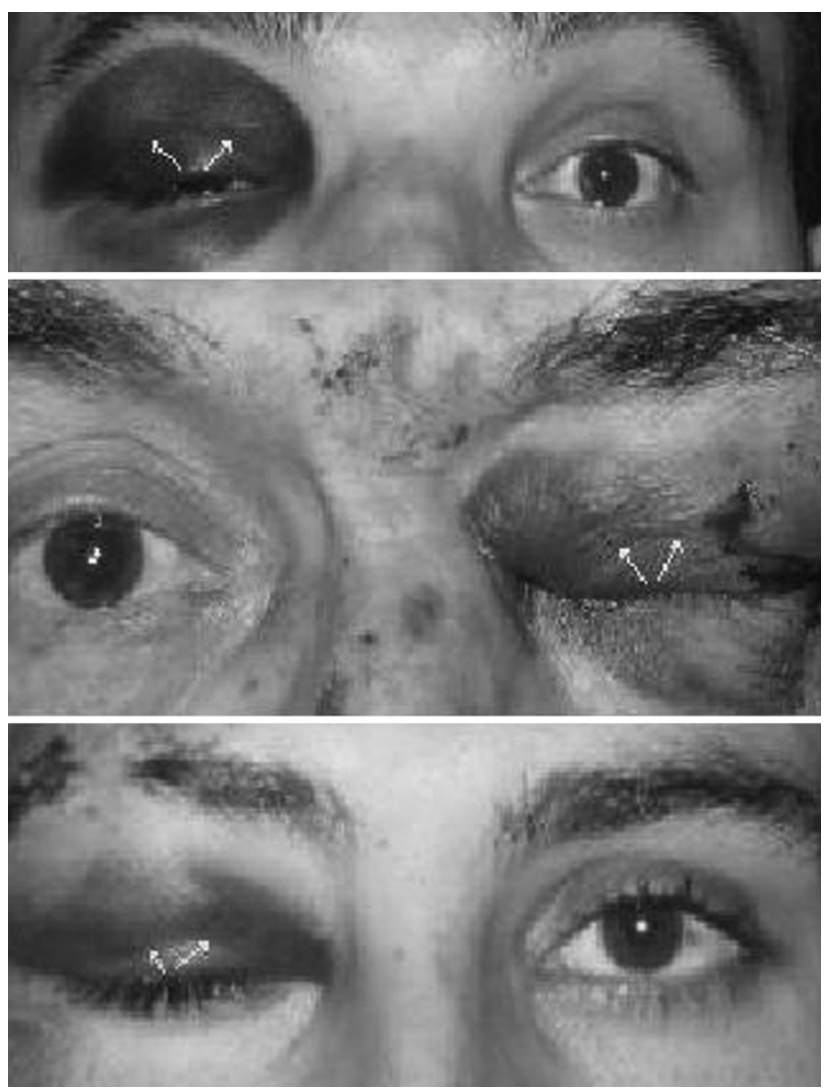

Figure 5. Three different patients with orbital trauma. Note that the skin crease is preserved despite periorbital edema and ecchymosis (arrows).

before assessment of a need for a surgical intervention. Superior branch of the occulomotor nerve lies parallel to the inferior wall of frontal sinus, thus in our case, the occulomotor nerve might have been affected from frontal bone fractures. We assumed that our patient's ptosis was resulted from the damage of the superior branch of the occulomotor nerve following the fractures of the anterior and inferior wall of the frontal sinus. However, the superior eyelid was not functioning and it didn't improve after six months.

After six months time, the levator function test was still $4 \mathrm{~mm}$. Ptosis was more severe at the lateral side of the eyelid. A secondary surgery including the frontalis suspension or levator resection was considered at that time. The severity of ptosis and levator function loss helps to choose the better management option ${ }^{3}$. In our case the ptosis was not severe and levator function was $4 \mathrm{~mm}$, thus we decided to perform a levator resection procedure. In non-traumatic cases, levator muscle is located under the preaponeurotic fat pockets below the orbital septum. In traumatic cases, fibrosis, atrophy of preaponeurotic fat pockets and deformation of orbital septum can complicate the surgery. Thus, the surgeon must be aware of that the secondary procedures are harder. In our patient we could find levator aponeurosis and resected it $10 \mathrm{~mm}$.

Common complications in secondary surgeries are bleeding due to fibrosis, conjunctival button hole formation, troubled localization and mobilization of levator muscle, notching of the eyelid and entropion ${ }^{4}$. We didn't experience any of these complications. In secondary surgeries, further fibrosis can be avoided by using cauterization cautiously. By limiting the resection at $18 \mathrm{~mm}$ in secondary surgeries, entropion may also be avoided ${ }^{4}$.

Traumatic neurogenic ptosis should be considered in the differential diagnosis of traumatic ptosis. Satchi et al. described three cases of neuropraxia of the nerves of the levator palpebrae superioris 5 . It is stated that traumatic neuropraxia to the innervation of the levator palpebrae superioris may occur in certain types of upper eyelid injury, most notably when there is significant forward traction applied to the upper eyelid. In our case traumatic neurogenic ptosis was not considered in differential diagnosis, hence there was an avulsion of levator muscle.

Craniofascial traumas need multi-systemic approach. Cooperation of neurosurgeons, plastic surgeons, otolaryngologists and ophthalmologists may prevent further complications which may be underestimated at emergency room, however may decrease future comfort of the patients. Skipping canalicular laceration, levator muscle laceration or small corneal perforation may result with repeated operations with lower optimal results and even result in organ loss. In conclusion, proper multidiciplinary approach to cases at ER will decrease the need for further surgeries and improve the patient's comfort.

\section{References}

1. Herzum H, Holle P, Hintschich C. Eyelid injuries: epidemiological aspects. Ophthalmologe 2001;98:1079-82.

2. Baroody M, Holds JB, Vick VL. Advances in the diagnosis and treatment of ptosis. Curr Opin Ophthalmol 2005;16:351-5.

3. Iliff JW, Pacheco EM. Ptosis surgery. In: Tasman W, Jaeger EA, eds. Duane's clinical ophthalmology. Philadelphia: Lippincott Williams and Wilkins; 2001.p.1-18.

4. Betharia SM, Kumar S. Levator surgery in post traumatic ptosis. IJO 1987;35:132-5.

5. Satchi K, Kumar A, McNab AA. Isolated traumatic neurogenic ptosis with delayed recovery. Ophthal Plast Reconstr Surg 2014;30:57-9. 